\title{
A modern tudomány előtti és azon kívüli név- és szófejtések alkalmazott vonatkozásai
}

1. Bevezető. Jelen dolgozat azon névfejtések, valamint általánosságban szófejtések funkcióját és utóéletét tekinti át, amelyek nem a mai, modern értelemben vett tudományos (azaz a történeti-összehasonlító nyelvészet módszereit és eredményeit felhasználó) etimologizálások eredményeiként születtek. Ide sorolhatóak egyrészt a modern tudományosság előtti etimológiák az európai antikvitásból, középkorból és a következő időszakokból a 19. századig, valamint az Európán kívüli népek mítoszaiban fellelhető név- és szófejtések. Másrészt a vizsgálat tárgyát képezik a modern tudományosság megjelenése után, azzal párhuzamosan akár máig fellelhető, ma tudományosnak nem tekinthető, laikus etimologizálások - így a népi eredetmagyarázatok vagy különböző ideologikus (pl. újnacionalista, ezoterikus) etimológiák stb. - is. Mivel a megjelölt téma igen tág, a tanulmány elsősorban az általános vonásokra, tendenciákra, tipikus megjelenési formákra koncentrál.

Az etimológiatörténet, különösen a névfejtések története, kivált, ha a tudomány elötti és az azon kívüli esetekről van szó, nem tartozik a sokat kutatott lingvisztikai témák közé. A nem tudományos szófejtések ugyanis a mai nyelvészeti diskurzusban legfeljebb tudománytörténeti érdekességként, furcsaságként vagy az adott szerző bogarasságaként, nevetséges próbálkozásaiként merülnek fel, részletes tárgyalásuk ezen túlmenően ritka. A magyar tudományosságban is kevesen foglalkoztak behatóbban ezzel a kortárs nyelvészeti szempontból kevésbé relevánsnak tartott témával, inkább külföldön jelentek meg ilyen jellegü tanulmányok és kiadványok, főként tudománytörténeti szemszögből vagy egy-egy szerzőre fókuszálva (pl. CURTIUS 1953, KLINCK 1970, HERBERMANN 1981, DEL BELLO 2007, BLUM 2012, MALES 2018). Az utóbbiak közül DAVIDE DEL BELlo könyve (2007) a legátfogóbb: a modern etimológia előtti és melletti európai etimológiai irányzatokról, szerzőkről ír, hangsúlyozva az allegorikus gondolkodás és az etimológia szoros kapcsolatát. Magyar vonatkozásban HALÁSZ IGNÁCZ írt antikvárius érdeklődéssel a magyar szófejtés történetéről $(1900,1903)$. A téma tulajdonnévi vonatkozásait HAJDÚ MIHÁLY foglalta össze (2003: 61-68); a kortárs laikus névetimológiákkal, illetve az ilyen névfejtéseket tartalmazó, nem tudományos igényü és jellegü kiadványokkal, köztük névszótárakkal, naptárakkal kapcsolatban pedig több névtani szempontú tanulmány is született a közelmúltban (FARKAS 2006, SLíZ megj. e., ZELLIGER 2017).

Tanulmányom célja annak bemutatása, hogy a tudomány előtti és tudományon kívüli etimológiák a nyelvészeti szempontból kifogásolható voltuk ellenére tanulságosak lehetnek, mivel egy-egy korszak, társadalmi csoport, szellemi irányzat gondolkodásmódjáról, világképéről árulkodhatnak; eszközzé válva különféle, nem nyelvi természetű célkitüzéseket szolgálhatnak; és a mindennapi ember életére is hatással lehettek és lehetnek. A szófejtés minden korszakban érintett közszavakat és tulajdonneveket is; a jelen írás ez utóbbi kategóriára kívánja a hangsúlyt helyezni, bár alkalmanként köznévi példák is feltünnek benne. A cél nem az etimologizáló törekvések történeti ívének végigkövetése - bár magyar nyelven erröl tudtommal nincs összefoglaló -, hanem általánosságban a céljaik, 
következményeik és módszereik áttekintése. A vizsgálat a készülő doktori disszertációmhoz is kapcsolódik: rávilágít arra, hogy az általam vizsgált mai laikus (köztük újnacionalista és ezoterikus) névfejtéseknek (IMREH 2014, 2015) milyen korábbi megjelenési formái voltak, milyen hagyományba ágyazódnak be, és az általuk alkalmazott módszerek milyen előzményekhez kapcsolódhatnak.

A dolgozat elején a tudományos és a nem tudományos etimológia kérdése áll a középpontban terminológiai szempontból. Ezt követően példákon keresztül az ide sorolható szó- és névfejtések céljairól, funkcióiról, módszereiről, végül pedig következményeikről és utóéletükről lesz szó.

2. Az etimológia a modern nyelvészeti módszerek létrejötte előtt és után. A tanulmány által tárgyalt kérdéskör nyelvészeti terminológiája számos kérdést felvet, melyeknek tisztázása nem ezen írás feladata, mégis érdemes néhány szót szólni róla. Az etimológia szó az ógörög etümosz 'igazi', valamint a logosz 'szó, beszéd' jelentésű szóból származó -lógia '-tan' szavak összetételéből jött létre, és az antikvitástól kezdve a szavak mögött álló dolgok igazi jelentésének, természetének a vizsgálatát jelentette a szinkrónia síkján, filozófiai és retorikai célzattal. A történeti nyelvészet módszereinek kialakulásával (pl. a hangtörvények felismerésével) a 19. századtól az etimológia a diakrónia, a szavak történetének kutatása felé fordult, és eszköz jellegét elvesztve önmagáért való tudománnyá vált (TRIER 2017). Az etimológia terminus manapság a nyelvészeti szakirodalomban a modern nyelvészeti szótörténeti kutatásokra foglalódott le, míg a nem nyelvészeti módszerekkel zajló szófejtések etimológia-ként való megjelölését rendszerint nehezményezik (pl. KÁlmÁN 1976: 165, TóTH V. 2008: 170). Munkám ezzel szemben az etimológia szakszót szélesebb értelmében használja, kiterjesztve minden olyan hajdani és jelenkori törekvésre, amely a szavak „eredeti értelmének”, alakjának, jelentésének, lényegének, eredetének feltárásával foglalkozik (vö. VENNEMANN 1999: 274). Ezenkívül az előbbi szinonimájaként az interpretáció és a szófejtés, illetve kimondottan a tulajdonnevek etimologizálására a névfejtés kifejezések is használatosak a tanulmányban.

A nem tudományos módszerekkel végzett egykori és mai szófejtéseknek nincsen összefoglaló nevük, ahogy egyes típusaiknak sincsen bevett nevezéktanuk. Kérdéseket vet fel például a modern tudományosság előtti etimológiák tudálékos-ként vagy tudomány elöttiként (vö. ném. vorwissenschaftlich) való megjelölése, hiszen azok többnyire a korukban tudományosnak számító módszerekkel dolgoztak, koruk tudományos színvonalán (VENNEMANN 1999: 275-276). Magam jobb híján a kissé körülményes, viszont pontos modern tudomány elôtti etimológia terminust alkalmazom a szófejtések előző körére. A modern tudományos módszertan kialakulása óta létrejött, azt nem ismerő és/vagy (akár tudatosan) nem használó szófejtéseket a laikus etimológia terminussal jelölöm (a laikus jelzőhöz vö. SÁNDOR 2011: 60-62). Ezek a nyelvből kiindulva próbálják megfejteni a szó jelentését, eredetét; az írásbeliségben élnek föleg, nem váltak közkeletüvé, szerzőjük többnyire ismert, visszakövethető. A jelen vizsgálatban a népi eredetmagyarázat (vö. TóTH V. 2008: 170), valamint népi etimológia szakkifejezést használom a korábban népetimológiá-nak is nevezett jelenségre vonatkozóan, amely a népetimológiá-val mint egy szóalkotási folyamat megnevezésével gyakran összekeveredik a szakirodalomban (pl. RÓNAI 1982, HAJDÚ 2003: 61-68). A népi etimológia vagy népi eredetmagyarázat alatt azok a (föleg hely-)név-, illetve szómagyarázatok értendőek, amelyek egy-egy történettel magyarázzák az adott szó vagy név eredetét, s kiindulópontjuk a szó vagy név hangalakja és/vagy jelentése, 
valamint a hozzá kapcsolódó konnotációk. Ezek szerzője nem ismert, mondhatni a mindennapi ember (,,a nép”) találta ki őket, maguk az etimológiák sokak körében ismertek, és a szóbeliségben élnek. A folklorisztika szempontjából e névmagyarázó történetek a monda müfajába tartoznak, tágabban szemlélve pedig a névvel kapcsolatos folklór - RUDNYCKYJ (1966) terminusával az ún. namelore - részét képezik. Ezeket a folklórszövegeket a néprajzban az eredetmondák, a történeti mondák vagy a helyi mondák közé szokták sorolni (NéprLex. névmagyarázó monda, helyi monda a.).

A megragadott jelenségeket a továbbiakban tehát - a terminusok pontatlansága és hibái ellenére, jobb híján - összefoglalóan a modern tudomány előtti és a modern tudományon kívüli jelzővel jelölöm, a tudomány alatt a történeti nyelvtudomány 19. századtól kezdve mára kialakult módszereit és eredményeit értve.

3. A modern tudomány előtti és azon kívüli szófejtések céljai, funkciói. Míg a tudományos etimológiák célja a szóalak és a jelentés alakulástörténetének, a nyelvészeti módszerekkel igazolható etimonnak a felderítése, addig a modern nyelvészeti metodika kialakulása előtti, illetve a jelenkorban azt figyelmen kívül hagyó szófejtések nem ezt a célt tüzik ki maguk elé. A szó- és névmagyarázatok rendszerint nem öncélúak, hanem eszközzé válnak egy olykor ki sem mondott cél elérésében. Míg a mai kor tudományossága hajlamos a szavak, nevek primitív fejtegetéseinek tartani a tudomány előtti etimológiákat, érdemes szem előtt tartani, hogy ezen etimológiáknak egyszerüen más volt a céljuk a maguk korában (DAVID 2009: 422-423), ahogy a modern tudományon kívüli etimológiák sem a tudományos megismerés igényével jönnek létre.

3.1. Megismerő-magyarázó funkció. Az etimologizálás ősi tevékenység: a megismerés, a világ megértése felé irányuló emberi ősszükséglet kielégítését szolgálja. Éppen ezért antropológiai univerzálé is, amelyet a gyermeki etimologizálás mindenkori jelensége és a névmagyarázó mondáknak a világ minden pontján való megléte is mutat. (WEISGERBER 1957: 80-81, TRIER 2017, HAJDÚ 2003: 61.)

3.1.1. Filozófiai megismerés. A mindenkori tudomány előtti és tudományon kívüli etimológia egyik funkciója ismeretelméleti jellegü: a világ dolgainak, müködésének filozófiai megismerésére tesz kísérletet, világmagyarázatot kíván adni (HERBERMANN 1981: 37, VENNEMANN 1999: 274). Ez legkézenfekvőbben az antik görög etimológiákban érhető tetten, például Platón Kratülosz-dialógusában, amely az európai írásbeliség talán legkorábbi és legalapvetőbb nyelvelméleti értekezése a Kr. e. 4. század első negyedéből. Ebben a neveknek, azaz platóni értelemben a szavaknak, tágabb értelemben a nyelvnek, valamint a világ dolgainak a viszonyáról beszélget Szókratész Kratülosszal és Hermogenésszel. Az előbbi szerint a név eredetileg az általa jelölt dolog lényegét írja le, az utóbbi szerint viszont a nevek konvenció útján jönnek létre. Jelen tanulmány szempontjából Szókratész etimológiái tűnnek ki a dialógusból, amelyekkel a vita egyes pontjait illusztrálja. Noha vitatott, hogy Szókratész mennyiben gondolta komolyan a szófejtéseit (DEL BELLO 2007: 58-59, BÖRÖCZKI 2008: 127-132), és társaival végül arra jut, hogy a nevük által nem ismerhető meg az adott dolgok valódi természete, szófejtései mégis figyelemreméltók. A filozófus istenek, mitológiai alakok, héroszok nevét, valamint filozófiai alapfogalmakat magyaráz, visszavezetve azokat a dolgok lényegét, a személyek főbb jellemzőit feltáró további, ismert jelentésü szavakra, szókapcsolatokra. Apollón nevére például 
a következő magyarázatot adja: ,aki lemos [apoluón] és megszabadít [apolüón] a bajoktól”; de kapcsolatba hozza az őszinteséggel (haplun); és megemlíti, hogy a nyilai mindig találnak (aei ballón). Platónnak a zenével és a csillagokkal-csillagászattal, valamint az azokban érvényesülő harmóniával kapcsolatos szerepkörére utalva hozzáfüzi Szókratész, hogy az isten együtt mozgat - homopolón - mely utóbbi szóból a homo- szótagot a-ra változtatva, valamint „még egy $l$-t is közbeszúrva” vezeti le az isten nevét, „mivel különben azonosan hangzana egy baljós jelentésü szóval" (apolón 'pusztító') (405 b-e / Platón 2008: 55; a forrásokból vett idézetek és példák kurziválása, helyesírása és jelölésmódja minden esetben az eredetit követi). Az EDG. szerint egyébként bizonytalan eredetü istennévröl van szó, amely talán a görög területek görögök elötti, nem indoeurópai nyelvéből származik.

Ugyancsak a világ megismerésére való igény volt a Kr. e. 4-3. századi sztoikus filozófusok (Zénón, Kleanthész, Khrüszipposz) szófejtései mögött, amelyekre valószínűleg Platón Kratülosza is hatással volt. A görög istenek és mitológiai szereplök nevének etimológiai vizsgálatával a különféle formában megjelenő, a világmindenséget kormányzó isteni hatalmat célozták megismerni, amelyet azonosnak tartottak a természettel, így allegorikus névmagyarázataiknak morális, fizikai, filozófiai vonatkozásai is vannak. Például Kleanthész szerint a Nap Apollón és Dionüszosz személyében is megjelenik, mivel különböző időszakokban különböző helyen kel fel (l. gör. ap' allón 'máshonnan [felkelő]'), valamint beutazza az égboltot (gör. dianüszai 'befejezte, bejárta [az útját]') (DEL BELLO 2007: 49-51, DOMARADZKI 2012). Az EDG. szerint egyébként, mint fentebb láttuk, az Apollón bizonytalan, a Dionüszosz pedig valószínüleg nem indoeurópai eredetü. Noha az etimológia a későbbi korszakokban elvesztette filozófiai jellegét, a megismerésben betöltött szerepe később újra és újra felbukkan a filozófiatörténetben, például Heideggernél (TRIER 2017, DEL BELLO 2007: 78-79).

A mai magyar, tudományon kívüli etimologizálások egyik irányzatában, mely a vizsgált szavakban ősi gyököket keres, szintén felfedezhető az etimologizálás filozofikus megismerésre irányuló funkciója. Ennek alapját az adja, hogy az e szellemben müködő szerzők szerint a magyar nyelv ösi gyököket tartalmaz, amelyek egyrészt az ősi magyar észjárás megismeréséhez segítenek hozzá (1. pl. Czakó 2008), másrészt egy ősi univerzális gondolkodásmódot tükröznek, mivel a magyar közel áll a világ (egyik) ősnyelvéhez (vagy éppen azonos vele). Varga Csaba szerint a magyar nyelv „,egységlogikában” gondolkodik: az egy a 'teljesség, tökéletesség' jelentéssel bír, míg a fél többnyire 'rossz, baljóslatú' (Varga 2003: 41). Az egységlogikát tükrözik az alábbi, a szerző által az egy szóból levezetett, pozitív jelentést hordozó szavak: igaz (azaz egy az), igazság, egész (azaz egy-ész - az igaz és az egész számára ugyanaz a szó), egészség, igazit, igazhitü, igazgyöngy, igen (azaz egyen), együtt, egylet, egybekel, igyekvö (azaz egyekvő, 'teljességre törő') stb. (Varga 2003: 47-51). A szerző elkülöníti a ,jó 1/2” és a ,rossz 1/2” fogalmát is: az előbbibe tartoznak azok a fogalmak, amelyeknek párjuk van - pl.feleség, felelet, megfelelö, félteke -; az utóbbiba pedig például a fél 'tart valamitől', féltékeny, félös, félrelép, félresikerült, félember stb., valamint a vál ige is (Varga 2003: 41-46). A szerző szerint „1 edül csak a magyar nyelv az, amelyiket döntően meghatározza az 1 fogalma, azaz nem számnévként (így is használatos persze), hanem elvont értelmében a teljes, egész kifejezéseként" (Varga 2003: 41). Ennek egyik bizonyítéka, hogy a magyar-angol szótárban az egy- kezdetü szavak tíz oldalt tesznek ki, míg fordítva, angol-magyar viszonylatban kevesebbet. A szerző példái: alone - egyedül = ledül, $\operatorname{mad}-$ félkegyelmü $=1 / 2$ kegyelmü, 
awkward - félszeg = 1/2szeg (Varga 2003: 41). A TESz. szerint nincs történeti összefüggés a példaként hozott szavak közt (egész, egy, igaz, igen, igyekvö, fél ${ }^{1}$, fél ${ }^{2}$, válik a.).

3.1.2. Spirituális megismerés. Az etimológia spirituális-transzcendentális jellegü megismerést is szolgálhat. Ennek legősibb példái a vallások szent írásaiban vagy az Európán kívüli népek mítoszaiban lelhetőek fel. A Védákban például mítoszformáló erőként, illetve a világ dolgai közti rejtett kapcsolatok mélyebb megértéséhez vivő eszközként jelenik meg az etimológia (BRONKHORST 2001). A Bibliában is számos olyan szó- és névmagyarázat található, amelyek továbbvisznek a vallási tanítások ismeretében. Ilyen például a Teremtés Könyvében a következő rész: „Az ember így szólt: »Ez már csont a csontomból és hús a húsomból. Asszony (isa) a neve, mivel a férfiböl (is) lett«." (Ter 2.23.) A teremtés- és a paradicsomi történetben a hasonló alak révén sajátosan egybejátszik a kollektív értelemben, 'ember; emberiség' jelentésben használt adam szó, az első férfi, Ádám neve, valamint a vele kapcsolatban álló 'föld' jelentésü adamah szó. (Az Ádám a klasszikus héber 'föld, talaj; ember' jelentésű szóból ered, amely egy 'vörös föld, talaj' jelentésű szóból származik; DMNES. Adam a., HENDEL 2000).

A spirituális világ szófejtések általi megismerhetősége a középkori gondolkodásban is megjelenik. Ennek legjelesebb példája Sevillai Izidor röviden Etymologiae címen emlegetett, húsz könyvből álló, a fizikai és a szellemi világról való korabeli tudást összefoglaló enciklopédiája a 7. század elejéről, amelyben az egyes szócikkeken belül a szerző az adott dolog nevének eredetét, magyarázatát is feltünteti. Szómagyarázatai filozofikus és vallási jelleggel is bírnak, például: amicus 'barát' < animi custos 'a lélek öre' (X. könyv 4.; az amicus valójában az amo 'szeret' igéből származik, 1. EDLOIL.). A homo ('ember') származtatása a humus-ból ('föld') a mai tudomány szemszögéböl éppenséggel helytálló (homo: indoeurópai eredetű szó, eredeti jelentése 'földlakó, földi lény' lehetett az EDLOIL. szerint). Viszont a hozzá füzött magyarázat Izidor korának keresztény szemléletét tükrözi: „Az embernek (homo) azért ez a neve, mert földből (humus) készült, miként az a Teremtés könyvében (2:7) is olvasható: »Akkor az Úristen megalkotta az embert a föld porából«.” (XI. könyv i. 4. / Isidore 2010: 231; angolból ford. I. R.; az ószövetségi idézet a következő kiadásból származik: Biblia 2006).

Jelenkori példaként a tulajdonnevek ezoterikus, például számmisztikai vagy asztrológiai magyarázatai kínálkoznak. E névfejtések célja az adott név mindenkori viselőjének a jellem- és sorsmagyarázata, amely mögött az ősi „nomen est omen” gondolat található meg. Például Takács Tibor az ábécé betüit egyes asztrológiai szimbólumokkal, Kliment Emília pedig számokkal párosítja, majd az előbbi szerző a név betűinek megfelelő szimbólumláncnak, az utóbbi a kapott számsornak az értelmezésével következtet a név mindenkori viselőjének a jellemére. Például a Réka név viselője az asztrológiai elemzés alapján többek közt a szavak és a meggyőzés embere, és kedveli az idegen kultúrákat (Takács é. n. 73), a számmisztika szerint pedig például elevenség, vállalkozó szellem, intelligencia, éleslátóság jellemzi, ugyanakkor gyanakvó és öntörvényü is, továbbá „,szívügye a természet, de matematikai-informatikai pályán is megtaláljuk" (Kliment 2005: 352). Az ilyen jellegü névfejtések rendszerint gyüjteményes formában, névszótárként a könyvpiacon is megjelennek (FARKAS 2006, SLíZ megj. e.).

3.1.3. A megismerő funkció pszichés vonatkozásai. Fontos megemlíteni a népi eredetmagyarázatok megismerésben betöltött szerepét is. A nyelvi rendszeren belül izolált, 
elhomályosult jelentésű, idegen eredetü vagy valamiképpen különös nevek értelmezésére gyakorta születtek eredetmagyarázatok, amelyekkel az adott közösség megindokolta az adott név létrejöttét. A kárpátaljai Bátyú falu nevének például háromféle magyarázata is ismeretes. Az első szerint a település alapítóiról kapta a nevét, akik nagy batyu-val érkeztek erre a helyre, a második Batu kán nevére vezeti vissza a toponimát (a tatárjárás idején itt ütött tábort a tatár vezér), a harmadik pedig a mocsaras, lápos, kátyú-s földrajzi környezetből magyarázza a nevet (MóRICZ 2013: 216). A helységnév a FNESz. szerint viszont puszta személynévből, magyar névadással alakult; a személynév (Bateu) első adatát 1274-ből ismerjük. Ezek a névetimológiák egyben pszichés funkciót is ellátnak: a helynévmagyarázó mondák a gyakran már elhomályosult motivációjú nevekkel teli tér pszichés belakásához, sajáttá, ismerőssé, otthonná alakításához is hozzájárulnak: „,a nép általuk veszi birtokba hazáját, szülőföldjét”" (RÓNAI 1982: 17).

3.2. Argumentatív funkció. A mindenkori szófejtések az ókori görög filozófiai megközelítésektől egyre inkább a praktikum felé tolódtak el, az érvelés és a grammatika szolgálatába szegődtek (DEL BELLO 2007: 78-79). Az ókori retorikában már Arisztotelész huszonnyolc érvfajtája között szerepel a nevek jelentése mint érv. Az argumentum a nomine példájaként a filozófus Drakón nevét hozza, akinek a törvényeiröl nevének 'sárkány' jelentésére utalva elmondható, hogy „nem is emberi törvények, hanem sárkány-törvények, olyan szigorúak" (Rétorika 2. könyv 23.29. / Arisztotelész 1982: 161; a drakón valóban 'sárkány'-t jelent, l. EDG.). Később Cicerónál és Quintilianusnál is megjelenik a névnek az etimológiai magyarázaton keresztül létrejövő érvfunkciója (CURTIUS 1953: 495).

3.2.1. Filozófiai érvelés. Az etimológia argumentatív, befolyásoló szerepe a közvetlen retorikai hasznosuláson túl több, közvetettebb szempontból is érvényesülhet, így egy ideológia, elmélet, filozófiai eszme, paradigma alátámasztása is történhet az annak megfelelő szófejtés révén. Szókratész a Kratülosz-beli etimológiái révén például rámutat arra, hogy a korabeli fluxuselméletet (azaz a „minden mozgásban van” elvét) szófejtésekkel is bizonyítani (illetve cáfolni) lehet. Így számos közszó etimológiájában megjelenik a mozgás motívuma, de személynevek értelmezésében is elöfordul. A filozófus - a fluxuselméletet megerősítendő - az Apollón személynevet a homopolón, azaz 'együtt mozgat' kifejezéssel is magyarázza. Értelmezésében a görög istennek a zenével, zenei harmóniával és a csillagászattal való kapcsolatára utal, mert ,ez az isten [...] felügyel az összhangra, és mindent egyszerre mozgat [polei hama] mind az istenek, mind az emberek között" (405 d / Platón 2008: 55).

3.2.2. Spirituális-vallási érvelés. Az etimologizálás célja lehet valamely vallási eszme, gondolat, tétel alátámasztása is, mint például a középkori keresztény szófejtések esetében. A korabeli etimológusok a keresztény tanítás beigazolását láttatták az egyes szófejtéseikben, amelyeket egyfajta misztikus megközelítés jellemzett, és a szimbólumok, példázatok, párhuzamok fontossága határozott meg (MALKIEL 1993: 1-2, DEL BELLO 2007: 43). Vallási szempontból kiemelkedő személyek (apostolok, egyházatyák, mártírok stb.) nevének magyarázata a korban a hozzájuk füződő szentkultusz erősítéséhez, az életpéldájuk keltette csodálat emeléséhez járult hozzá. Sevillai Izidor is értekezett bibliai személyek nevéről, de az ő írásainál sokkalta nagyobb népszerüségre tett szert egy későbbi középkori legendagyüjtemény, Jacobus de Voragine Legenda aurea címü, az 1260-as 
években készült műve. A középkori szentkultusz virágzása idején méltán közkedvelt mű a katolikus naptár rendjében mutatja be egyenként a legismertebb szentek életét. A fejezeteket a szerző sok esetben az adott személy nevének elemzésével kezdi, megelőlegezve az adott szent életéből leszürhető erkölcsi tanításokat, és összefüggést teremtve a névviselő és annak neve között. (MADAS 1990: 318.) Például Alexandriai Szent Katalinról ez olvasható: „Katalin (Catherina) a catha, azaz 'egyetemes' és a 'romlás' (ruina) szavakból származik, s annyit tesz, mint 'egyetemes romlás', mert egyetemesen lerombolta az ördög összes építményét. Összerombolta a gőg építményét a benne élő alázat által; a testi vágyét megőrzött szüzessége által; a földi mohóságét a földi dolgok megvetése által. Vagy Katalin annyi, mint 'láncocska' (catenula), mert jócselekedetekből láncot kovácsolt, melyen fölhágott az égbe. Ennek a láncnak vagy létrának négy foka volt: a cselekvés ártatlansága, a szív tisztasága, a hiú világ megvetése és az igazság szólása.” (Voragine 1990: 297.) A Katalin a modern tudományos etimológia szerint görög eredetü, bizonytalan jelentésü. A KnE. szerint a katharosz '(mindig) tiszta', illetve Aikatheriné 'nyilazó, biztosan célzó' szavakkal áll kapcsolatban, a DMNES. szerint (1. Katherine a.) az előbbivel nem áll rokonságban, csak később kapcsolták hozzá.

Hasonlóan szemléletes a korában alacsonyabb presztízsünek számító szláv, világi László névnek a presztízsemelése a Szent László-legendában a görög nyelvből való származtatással (SLÍZ 2011: 12): „Imígyen a kegyelem emez első ajándékaival született, a neve pedig László lett, s úgy látszik, kiváltképpen az eljövendők elöérzetében adták neki e nevet. Mert ha nevének etimológiájával enyelgünk, »Ladislaus« a népeknek istenadta dicsőségét jelenti. »Laosz«-t ugyanis »nép«-nek fordítják, »doszisz« pedig: »adó« vagy »adott«, illetve »adás«. Nevének első szótagja pedig szótagtoldással: »dicsőség«" (Érszegi 1987: 95). A László a 'hatalom' és a 'dicsőség' jelentésű tagokból álló szláv Vladislav névböl származik (KnE.).

3.2.3. Hatalmi célú érvelés. A tudomány előtti és a tudományon kívüli szófejtés bizonyos történetileg indokolható előjogok, kiváltságok, hatalmi status quók igazolására is alkalmas. Ez legföképpen a középkori történetírói munkákban teljesedett ki, ahol a névfejtés az adott nép, település, állam vagy személy eredetét, történetét bizonyító érvelésrendszer jóformán állandó elemei közé tartozott (WEISGERBER 1957: 82-85, DAVID 2009: 422-423). Népek, államok származtatására példa a briteknek Brutustól, a frankoknak pedig egy római kori helynév (Colonia Ulpia Traiana, a mai Xanten egykori latin neve) alapján a trójaiaktól, illetve azok vezetőjétől, egy bizonyos Francótól való eredeztetése (WEISGERBER 1957: 83-84). Etimológiai alapú eredetmonda révén tett szert ősi eredetre Trier városa egy Trebeta nevü városalapító révén, aki a város alapítási mondájában Szemirámisz mostohafiaként szerepel, vagy Reims a Rómát megalapító Remustól való eredeztetés következtében (WEISGERBER 1957: 84). Ugyanebbe a sorba illeszkedik Anonymus a maga sajátos munkamódszerével, amellyel kora helyneveit kreált történelmi szereplőkre vezette vissza. Célja mindezzel egy olyan honfoglalás-történet megalkotása lehetett, amely a királyi ház dicsőségét, legitimációját, valamint kora egyes nemzetségeinek birtoklási jogait támasztja alá történetinek tünő érvekkel (1. pl. BENKÖ 1998: 11, 1. továbbá FARKAS 2019).

Az előzőekhez kapcsolódnak azok a szó- és névfejtések is, amelyek a nyelv történetére vonatkozó állításokat támogatnak meg. Erre tudomány előtti és tudományon kívüli példákat is találhatunk. A nyelvrokonság alátámasztása etimológiákkal nem a történeti 
nyelvtudomány kialakulásától veszi kezdetét: a kora újkorban szokás volt - a nyelvi nacionalizmus korai megnyilvánulásaként - az akkoriban a világ ősnyelvének tekintett héberből magyarázni az anyanyelvet. Ezt tette a holland Johannes Goropius Becanus (Jan van Gorp), aki az 1569-ben írt Origines Antwerpianae című müvében amellett érvelt, hogy az amszterdami dialektus a paradicsom nyelvét, azaz az emberiség Bábel előtti ősnyelvét és egyben annak ősbölcsességét őrizte meg. Tézisét többek között bibliai személynevek holland szavakra való visszavezetésével támasztotta alá; pl. Noé (holl. Noach) : noot-acht 'a szükségre figyelő', ugyanis az özönvíz átvészelésére bárkát épített; Ádám (holl. Adam) : hat-dam (holl. 'gyülölet-gát', mivel a kígyó Ádámot nem, csak az asszonyt tudta rosszra csábítani, és így hozta el a gyülöletet a világba; KROP 2016: 111-112). Tevékenysége nyomán alakult ki a goropizmus vagy becanizmus kifejezés a hasonló „vágyvezérelt etimológiákra” (1. az angol fordításban „etymological wishful thinking”, ECO 1995: 96).

Becanus etimológiai munkásságának magyar párhuzamait a korai, 15-19. századi magyar etimológiai magyarázatok adják, amelyek mögött a magyarság presztízsnövelésének vágya fedezhető fel (1. HAJDÚ példáit; 2003: 62-63). Az ebböl a szempontból leghírhedtebb 19. századi történész, Horvát István például bibliai személyneveket magyar nevekkel feleltetett meg, a magyar nép ősiségét bizonyítandó: „Pözsög a’ Szent Írás mindenfelé a' régi Magyar nevektől és régi Magyar Irás módtól" (Horvát 1825: 19). Hasonló a Petőcz Mihály esete: Régi magyar szavak című munkájában (1840) számos közszó és tulajdonnév etimologizálásával igyekszik rekonstruálni a magyarok ősi világképét és kultúráját. Szerinte a magyarság egyfajta ősnépként élt Európában, de a történelem folyamán - például a rómaiak pusztításai miatt - a ösi területeiröl visszaszorult, és a hon visszafoglalása idejére nyelvük elromlott. Például az Ócsa helynév szerinte a 'régi' jelentésű ó és egy csa szó összetétele. Az utóbbi jelentését úgy fejti meg, hogy Ócsán egy ó, régi dolgot keresve a templomot találja a legrégibbnek: „O-csa tehát ó-templom volna és »csa« volna a templom eredeti magyar neve: mert hogy templom nem magyar szó, hanem a latin »templum« szótul eredt, azt mindenki tudja" (Petőcz 1840: 35). A csa szóból vezeti le aztán számos közszó eredeti jelentését (csacsogás 'prédikáció', búcsújárók $\sim$ bú-csa-járók 'akik bánatukban felkeresik a templomokat', furcsa forcsa 'forrás melletti templom, ahol ma furcsának nevezett dolgok történnek', csintalan csántalan csatalan 'istentelen, templomból kizárt ember' stb. Petőcz 1840: 40-47).

Az előbbiekhez hasonló célú etimológiák megfigyelhetőek a közelmúltbeli és jelenkori laikus nyelvrokonság-keresésben is. Ez ugyanis a finnugor nyelvrokonság bebizonyosodása óta is folytatódik, hiszen az ide sorolható szerzők nem fogadják el annak érvényességét. Az ilyen célú szófejtés közszavakon kívül tulajdonneveket is érint, és két fö iránya van. Az első irány egy presztízsnyelvből való származtatás (sumer, török, hun stb.). Bobula Ida például sumer „ősszavakból” magyarázott magyar családneveket, például a Szabad-ot, valamint a nyilvánvalóan helynévi eredetü Szabadossi, Szabadkai, Szabady családneveket egy $\breve{S} U-B A R$ 'kéznyitás, szabadítás' jelentésű sumer „ősszóból” származtatja (1970: 75). (A szabad a TESz. szerint szláv eredetű szó.) A másik irány a mai magyar szavak, tulajdonnevek ősi magyar gyökökre való visszavezetése. Faragó Imre például kelet-közép-európai helynevekben feltételez ösi magyar gyököket, alátámasztandó, hogy „,a magyar nyelv áll legközelebb az ősnyelvhez, sőt, a magyar nyelven beszélö népesség él a legrégebben itt Európa szívében, a ma beszélt nyelvek alapjai innen rajzottak szét” (Faragó 2016: 12). A gyökökre visszavezető érvelés például a Beszterce település- és 
folyónév kapcsán is látható művében. A toponima szerinte a magyar besz 'hadakozik; erőlködik' (vö. bösz), ter 'szélesedés' (vö. tér, tör) általa feltételezett gyökök, illetve a -ce helynévképző kapcsolatából alakult ki, így szerinte a Bystrica, Vydrica, Bystrzyca, Feistritz, Weisseritz kelet- és közép-európai toponimák is magyar eredetre vezethetők vissza (Faragó 2016: 135-143). A Beszterce helynév a FNESz. szerint egy ősszláv *bystrica 'gyors folyású (és ezért többnyire tiszta, átlátszó vizü) patak, folyó' jelentésű szóból származik (vö. pl. szerb Bïstrica; Faragó müveinek névtudományi értékelésére 1. ZELLIGER 2017). Hogy a jelenség nem magyar sajátosság, azt például az ausztriai laikus helynévetimologizálások megléte is mutatja: Inge Resch-Rauter például kelta nyelvi, kulturális, vallási örökség örzőiként interpretálja az osztrák helyneveket (HOHENSINNER 2015: 150-155).

Az előjogok igazolása, az eredetkeresés és -bizonyítás köréhez további jelenkori példaként szolgálhatnak a Pilis-kultusz tudományon kívüli etimológiái is, amelyek célja annak a feltevésnek az igazolása, hogy a Pilis vidéke, kivált Dobogó-kő környéke történeti és spirituális értelemben is kiemelkedő szerepet játszott és játszik a magyarság és az egész világ történetében, sorsában. A Dobogó-kő név például e felfogás szerint a királyi koronázások itt feltételezett helyére és arra a képzetre utal, hogy itt található a Föld szívcsakrája (1. bövebben IMREH 2014, 2015).

Mint látható, az ilyen igényü, tudományon kívüli etimológiák végső soron nem is a nyelvről, hanem a nyelvet hordozó népcsoport történetéről és erényeiről akarnak mondani valamit. A szófejtések által megtámogatott dicső múlt képe révén pedig az arra alapozott nemzeti önkép is pozitívabbá válik.

3.3. Narratív-szórakoztató funkció. Egyes szófejtések epikus formát is ölthetnek: a történetmesélés és -felidézés mindenkori igényét tölthetik be a mindennapi ember számára. Ez a funkció a fent idézett középkori szentnév-interpretációkban jól megragadható, de ezt megelőzően már az ógörög epikában, jelesül Homérosz és Hésziodosz müveiben is fontos szerepet játszott. A nevek itt beszédességük, jelentésességük révén alapvető referenciális, a narrációt támogató eszközök, ami a müfaj orális előzményeiből is magyarázható (KANAVOU 2015: 1-28). Az olykor kifejtett etimológiák kisebb epizódokként illeszkednek a történet folyamába, a nevek így lehetőséget adnak a történetmesélésre (DEL BELLO 2007: 66), önmagukban „sürített szüzséként” működnek (SLíz 2013: 224). Hésziodosz például Aphrodité nevét így magyarázza: „Aphroditének, »habszültének«, vagy Küthereiának, koszorúsnak hívják istenek és a halandók, mert a habokból lett, s aztán a küthérai néphez jött el először" (Istenek születése 195-198 / Hésziodosz 1974: 13).

További példák erre a népi eredetmagyarázatok, amelyekben kis történetek kerekednek egy hely- vagy személynév kapcsán. Ezek létrejöttének célja a szórakoztatás is (DÖMÖTÖR 1991: 125). A kárpátaljai Técső város névmagyarázó mondája két másik közeli mikrotoponimát is megmagyaráz. Ennek lényege, hogy egyszer régen ellenség támadt az országra, és a királyné éppen erre a tájra menekült. A harcok közben önmagát feláldozva egyik udvarhölgye a királyné felé tartó nyílvessző elé ugrott, és halála előtt pirkadatkor a hegyen szétnézve, amelyre fölmenekültek, így szólt: „Felséges asszonyom, teccő nekem ez a hely” (innen a Técső név), majd halála közeledvén így kiáltott fel: „Úrnőm, ne eresszen el!" (innen a közeli Nereszen hegynév). A királyné az elhunyt sírjára a síkság közepén földet hordatott, majd kápolnát emeltetett (innen a közeli Kápolna dombnév) (MóRICZ 2013: 221-222). A FNESz. szerint a Técső toponima puszta személynévből, magyar névadással alakult városnév, s a személynévre 1200-ból hoz adatot (Tecu). A Nereszen 
hegynév eredete a Kárpátalja helyneveit kutató SEBESTYÉN ZSOLT szóbeli közlése szerint egyelöre ismeretlen.

Itt említhető meg a tudományon kívüli etimológiák azon csoportja is, amelyeknek fő céljuk a humoros hatás elérése. A játékosság a népetimológiás szóalkotási folyamatok egyik ösztönzője is lehet, bár itt a tudatosság, szándékosság motívuma miatt a népetimológia helyett inkább szóferdítésről, szójátékról van szó (vö. OLSCHANSKY 1996: 171-173; pl. nyugdíjas - nyögdijas, diszpécser - díszpancser, agronómus - ugrómókus; mojito - molyirtó, marihuána - marihónalja; KovALOVSZKY 1967: 246-247, ill. DÉvA 2010). Nevek kapcsán is alakulnak ki humoros variánsok, amelyeket ZOLNAY VILMOS ál-népetimológiás ragadványneveknek tekint (kéziratos anyag alapján említi KUGLER 1993: 205, pl. Badoglio : Bádog Leó, Kisfaludy Stróbl Zsigmond : Giccsfaludi Stréber Zsigmond). Hasonló névferdítések figyelhetőek meg manapság a szlengben (pl. Hajdúszoboszló : Szoposzló, Szop City, Gajdultszoboszló stb.; Szabadszállás : Szivatszállás, Szutyokszállás stb., GYŐRFFY 2011: 95-96).

A tréfás szándék a tulajdonnevek egyes tudományon kívüli interpretációi, eredetmagyarázatai mögött is megfigyelhető, így számos népi helynévmagyarázatban is. Novaj falu nevéhez például az a magyarázat kapcsolódik, hogy egy koldus ,életében először vajat kapott, ám nem tudva, mitévő legyen, zsebre tette az ismeretlen portékát. Később persze hült helyét találta a szétolvadt zsiradéknak, s bosszúsan dörmögött: ,,No, vaj, no, vaj” (DÖMÖTÖR 1991: 126). A viccek között is van hasonló: „Mit mond a kínai, ha egyszer megkóstolja a francia ételeket? Pá, rizs!"

Az élénk asszociációkat keltő, különleges névhangulatú helynevek a szépirodalom számára is szolgáltatnak anyagot (BALÁzS 2008: 352-353, SZIKSZAINÉ NAGY 2015), ahogy azt Csukás István Gilice-síp, Tamkó Sirató Károly Vándor Móka, Varró Dániel Gasztronómiai limerickek című verse (és általában a limerick műfaja), vagy Pusztay János Topopoezis címü verseskötete is példázza. Közszavakat magyaráz Babits Mihály „nyelvtudományi humoreszkjében”, amely a magyar régmúltat firtató laikus etimológiák paródiájaként olvasható (Babits 1938). A keresztnevekre tekintettel Sipos Ferenc sajátos összeállítása a legátfogóbb vállalkozás, amelyben a következőhöz hasonló névmagyarázatok olvashatóak: Cecília: „Ösmagyar női izgatónév. Eredeti alakja »Cicilia«. »Lia« utótagja úgynevezett gyönyörképző, az előtte álló dolog kellemes mivoltát emeli ki: élvezetes ízű például a vanília, szemet simogató a dália és a dalia, puha tapintású a zsenília és a bársonyos monília. ([...] eleink [...] a moníliás szilvát, meggyet, vagy egyéb gyümölcsöt [...] még éppoly ínyencségnek tartották, mint mi a nemespenészes sajtokat.) A »Cici« előtag értelme ma sem ismeretlen senki elött, akit eleven anya hozott világra. [...] A teljes keresztnév jelentése tehát: »jóózü, kellemes tapintású, szemet gyönyörködtető kebellel bíró nőszemély«." (Sipos 2012: 73).

4. A tudomány előtti és laikus névfejtések módszerei. A mindenkori tudományon kívüli név- és szófejtések módszereiben sok rokon vonás fedezhető fel, így a mai kortárs laikus etimológiák vizsgálata során is érdemes szem előtt tartani, hogy módszereiben sem új jelenségről van szó. A laikus, olykor nyakatekert etimologizálások mindenkor meglétét mutatja a „lucus a non lucendo” ('az erdő szó a nem világító-ból', - ti. az erdő sötét) antik etimológia is, amely a 'furcsa, némileg erőltetett szómagyarázat' jelentéssel szállóigévé is vált (HALÁSZ 1903: 3, WIEGAND-CZANYUGA 1864: 165). 
A modern nyelvtudomány előtti és azon kívüli laikus szó- és névfejtések első ránézésre sokszor nem követnek szabályokat a szavak, nevek történetének, eredetének, jelentésének vizsgálatakor. Látszólag Platón Kratüloszában sincsenek megkötések a szó- és névfejtések mikéntjét illetően (BÖRÖCZKI 2008: 131). Erre maga a filozófus is reflektál: „ha azonban valaki megengedi, hogy az ember tetszése szerint beletehet a nevekbe meg kivehet belölük, amit csak akar, akkor könnyüszerrel hozzá lehet igazítani bármelyik nevet bármelyik dologhoz", majd az ebbéli mértéktartásra hívja fel a figyelmet (414 d-e / Platón 2008: 71). Az etimologizáló tehát nem kezelheti teljesen szabadon az általa vizsgált szóanyagot, különben hitelét veszítené. Noha pontosan megállapított és következetesen betartott metodikával nem nagyon lehet találkozni a vizsgált anyagban, a szavak értelmesítése, a szóalaknak a forrásszóhoz való alakítása gyakran a mindenkori nem tudományos etimologizálásokban is lehetséges és tipikus elvek, módok alapján történik. Ezeket bizonyos korlátok között alkalmazva a szerző eredményei a laikus olvasó számára még elfogadhatónak, logikusnak és így tudományosnak is tünhetnek.

Kratülosz-beli etimológiáiban - tehát a praktikumban - már Szókratész (azaz Platón) felvonultatja jórészt az összes módozatot, ahogyan a szavakat, neveket az értelemadás céljával módosítani lehet, de csak néhány helyen utal elméleti kérdésekre. A szisztematikusabb, etimológiagyüjteményként is funkcionáló müvekben néhol viszont explicite is megjelenik a módszertan. A sztoikusok módszereinek összegzése Szent Ágoston 387 körül írt De dialectica címü müvében maradt az utókorra (6. fej., Augustine 1975: 91-99). Röviden tért ki a módszertanra Varro a Kr. e. 40-es években írt De lingua latina címü müvében (5. könyv 6. fej., Varro 1938: 6-9) és Sevillai Izidor az Etimológiákban (I. könyv 29. fej., Isidore 2010: 54-55). A kortárs gyökelméletre a módszerek részletes taglalása különösen jellemző (1. Varga 2003: 26-34 stb., Faragó 2016: 17-55).

Az ilyen helyeken felsorolt metódusok kettős funkciót látnak el. A szerzők egyrészt ezekkel mint elvekkel magyarázzák a szavak létrejöttét és módosulásait, másrészt a szófejtéseikben módszerként használják fel őket, amelyekkel a szavak visszavezethetők eredeti alakjukra és ezáltal jelentésükre. A továbbiakban ezen elvek és módszerek közül a legfontosabbak vázlatos bemutatása következik, részben az adott szerző szöveges megállapításai, részben saját észrevételeim alapján.

4.1. Onomatopoézis - az egyes hangoknak tulajdonított jelentés. Az egyik és talán legnépszerübb történeti és szómagyarázó elv az onomatopoézis. Eszerint a szavak úgy keletkeztek, hogy az egyes hangjaik a természetben fellelhető zajokat vagy egy bizonyos hangulatot, benyomást adnak vissza - és fordítva: amennyiben ismerjük az egyes hangokhoz kapcsolódó képzeteket, megfejthető az adott szó származása, eredeti jelentése. $\mathrm{Az}$ onomatopoézis a szavak létrejöttének és helyességének egyik magyarázó elve a Kratüloszban, a sztoikusoknál és Sevillai Izidornál is. A sztoikusok elveit rögzítő Szent Ágoston írásában például a 'kereszt' jelentésű crux hangzásbeli keménysége, durvasága a keresztre feszített fájdalmára emlékeztet, míg a 'gyapjú' jelentésű lana az anyag puhaságára (De dialectica 6. / Augustine 1975: 94-95).

A kortárs laikus etimologizálások körében ez az elv legerőteljesebben a gyökmódszerben van jelen. Az ide sorolható szerzők rendszerint a CzF. etimológiai elveiből merítkeznek, azokat akár egyben át is veszik: Varga Csaba átemeli a CzF. gyökszótárát (2003: 338-447), Czakó Gábor erre a módszerre alapozza „nyelvrégészetét” (1. pl. 2008: 63-150), és sajátos nyelvtankönyvet is ír a CzF.-re építkezve (2011). A CzF. a hangváltozási 
törvényszerüségek felismerésén alapuló történeti-összehasonlító nyelvészetet megelőző, 19. század eleji, organikus, humboldti-herderi nyelvészeti paradigma keretében végezte a szavak származtatását, rokonítását (vö. ROBINS 1999: 156-161, NÉMETH 2007: 69-71, 91-100), és abban az egyes hangok jelentésességének nagy szerepe volt (1. pl. a CzF. Előbeszédében, 57-58, illetve a szótáron belül az egyes betük bevezetésénél).

Faragó Imre (2016) gyökelméleti alapon magyaráz közép-európai helyneveket. Könyve bevezetőjében a hangok és a két-három hangból álló gyökök jelentésességéről is értekezik (Faragó 2016: 25-61), majd észrevételeit a helynevek magyarázatában is érvényesíti. A Pilis toponimát például egy pil gyökkel magyarázza, amelynek ,alapjelentése: 'élénk, könnyed mozgás, lebegés””, továbbá ,a »pili« relatív gyök jelentése 'pihe, pehelyféle szálacska'[,] ezek valamilyen testről, egészről levakart, leváló részecskék. Ennek nyomán a »pilis« egyik jelentése 'levakart, lereszelt"”, majd utal többek közt a szerzetesek kiborotvált fejtetőjére, pilisére. Később így folytatja: „A »pil« gyök egy alapú a »fil« vagyis »fel«, »föl« gyökökkel. Így a »pilis« eredetileg 'fölös' vagyis 'felső'. Ugyanakkor a »pil« rokon a »vil« gyökkel ennek jelentése 'világos' vagyis 'kopasz' sőt az előzőek alapján 'kopasz, tar felső rész'. Mindezek összegzéseként a »pilis « = 'magasan fekvő, kopasz (világos) tető’” (Faragó 2016: 145). Figyelemre méltó, hogy más úton, de közel azonos jelentésre jut, mint a toponimát valamely szláv nyelvből eredeztető FNESz. (1. „kopasz hegytető; növényzet nélküli, kopár hely”).

Bár nem az onomatopoézishez tartozik, és nem is nyelvi jelentésviszonyokon alapul, de itt érdemes még utalni a korábban már említett kortárs ezoterikus névelemző módszerekre, amelyek a név egyes betűihez számmisztikai, illetve asztrológiai alapon jelentéseket kapcsolnak. Amennyiben a név hangalakjából kiinduló értelemadásról, jelentéstulajdonításról van szó ezek esetében, annyiban a különös módszer ellenére az etimológia körébe lehet sorolni az ezotéria névmagyarázatait is.

4.2. Magyarázat egy azonos nyelvi szóból. A modern tudomány előtti és azon kívüli etimológiák jelentős része egy adott szót egy másik, a szinkróniában meglevő, azonos nyelvbeli szóból magyaráz. A két szó hangalakilag rendszerint közel áll egymáshoz, jelentésük összekötése pedig valamilyen hosszabb értelmezéssel (például a népi eredetmagyarázatokban) vagy rövidebb indoklással (pl. a Kratüloszban) történik.

A két dolog, fogalom közti jelentésbeli viszony többféle lehet. Ezeknek jellemzőbb típusait - mint a szavak keletkezésének lehetséges útját és egyben mint az eredeti jelentés visszafejtésének elvét - Szent Ágoston (a sztoikus szófejtést illetően) és Sevillai Izidor is elkülönítette. Ilyen például a similitudo, azaz a hasonlóság elve, amely a két fogalom közti metaforikus viszonyt jelenti (erről 1. DEL BELLO 2007: 75). Szent Ágoston példái közt a crus ('láb') összekapcsolása a crux ('kereszt') szóval a hasonló hangalakból indul ki, de a két dolog hosszúsága és keménysége is szerepet játszik az összekötésükben (De dialectica 6. / Augustine 1975: 95). Ide tartoznak a gyökök elkülönítésén alapuló kortárs laikus etimológiák szófejtései is, ahol némiképp hasonló alakú szavakat kapcsolnak össze a jelölt dolgokban, fogalmakban fellelt közös vonások alapján. Például a kör, kerités, kert, kerámia, görbe, valamint a latin (sic!) curved 'görbe', az angol garden 'kert', church ('körtemplom'-ként értelmezve) és a német Kirche szavakat Varga Csaba a feltételezett, kerekséget kifejezö kör, ker, kar, gör stb. gyökcsaládra vezeti vissza (Varga 2003: 31). 
A vicinitas, azaz a közelség elve egyfajta érintkezésbeli, metonimikus viszonyt tükröz. Ennek Szent Ágoston számos típusát felsorolja (Augustine 1975: 95-97). Ilyen például a valamiben benne levés (pl. az urbs 'város' az orbis 'kör'-böl, amelyen belül a szántással való kijelölés után a város megépült), vagy az elnevezendő dolog okáról, illetve előzményéről való elnevezés (pl. foedus 'szövetség' a foeditas porci 'a disznók piszkossága' kifejezésböl, ti. szövetségkötéskor disznót vágtak). Ez utóbbi elven müködnek a népi helynévmagyarázatok közül azok, amelyek az adott toponimát egy történet kulcsszavára vagy személynévre vezetik vissza (DÖMÖTÖR 1991: 126). Például az egyik helyi monda szerint Mátyás király kisfiától egy holló ellopott egy köves gyürüt, így jött létre a Hollókő helynév (DÖMÖTÖR 1991: 126).

A harmadik - és a tudományos etimológia szempontjából valószínűleg a legfurcsább - jellegzetes magyarázati elv, amelyet az ókori és középkori etimológia számon tart, a contrarium, azaz az ellentét, amelyet megtalálunk Szent Ágostonnál (lucus quod minime luceat 'az erdő [...], mert kevés fény van benne', bellum qoud res bella non sit 'háború, mert ez nem szép dolog', Augustine 1975: 96-97). Varrónál például a caelum 'ég, égbolt' az egyik magyarázat szerint az 'elrejtett, titkos' jelentésű celatum-ból lett (De lingua latina 5. 18. / Varro 1938: 17-19), de Sevillai Izidornál is előfordul (pl. lutum 'sár' a 'megmosott' jelentésü lutus-ból, I. könyv 29. 3.).

4.3. Magyarázat több, azonos nyelvi szóból. Az etimologizálások másik típusa az adott szót, nevet több más szóból, azaz egy szókapcsolatból vagy egy mondatból vezeti le, ahol a forrásul megadott szavak és a magyarázandó szó között akár néhány betűnyihangnyi megfelelés is elegendő. Ilyen például a Kratüloszban a Démétér istennév az 'ajándékozó anya' jelentésű didusza mété-ből (404 b-c / Platón 2008: 53) vagy a Dionüszosznak a didusz oinon 'aki a bort adja' jelentésű szókapcsolatból való magyarázata (406 c / Platón 2008: 56). Izidor hasonló módon világítja meg például az amicus ('barát') szót az animi custos ('a lélek öre') szintagmával (X. könyv A. 4. / Isidore 2010: 213). A népi helynév-etimológiák egy része is így müködik: Hollókő például egy másik monda szerint egy kisfiú felkiáltásáról kapta a nevét: „Apa, nekem holló kő!” Hasonlóképpen, a Félegyháza nevet abból a mondából származtatták, hogy egy hercegné a környéken szállást keresve csak egy házat talált, és azt mondta, hogy ő fél egy háznál megaludni (DÖMÖTÖR 1991: 126).

Ennek a válfajnak - noha már az antikvitásban is erősen jelen volt a gyakorlatban - a 12. században nőtt meg a produktivitása a szófejtő gyakorlatban. Ettől kezdve az etimológiának két típusa különült el a téma kutatói szerint: az előbbi, több szóval magyarázó, inkább már játékosan müködő expozíció, valamint a korábbi, szóeredet-kereső, általában egy másik szóból származtató deriváció. Ezek között végeredményben nem az alkalmazott technikában, hanem az eredmények prezentálásában van a különbség (pl. a 'mert' jelentésű quod kötőszavas szómagyarázatok helyett a quasi 'mint, miként, mintha, kvázi' kötőszó használata; minderről BLUM 2012: 61-64). Ilyen például a két etimológiatípus közti különbségre rávilágító 12 . századi szerző, Petrus Helias magyarázata a fenestra 'ablak' jelentésű szóhoz: „quasi ferens nos extra”, azaz 'kvázi kivisz minket' (idézi BLUM 2012: 61).

A Pilis-kultuszhoz kapcsolódó etimológiákban - főként az ezoterikus jellegüekben szintén az előbbihez hasonló, asszociációs jellegü kapcsolat figyelhető meg. Például Born Gergelynél a Pilis névről ez olvasható: „A Pilisnek már az elnevezése is igen »beszédes«! 
Éppúgy ott bujkál e névben a PóLuS-jelleg, az ősi szerelemvallásunkra utaló PáRoS müködés vagy a fejtető és a kenyér szélének(!) régi magyar PiLiS elnevezése, mint az itt található szent helyeket őrző és müködtető PáLoSoké.” A szerző továbbá részletesebb magyarázat nélkül összeköti a toponimát egy Peles/Palos/Pilis nevü jász királlyal, a görög mitológia Palos-ával, valamint Akhilleusz apjával, Péleus királlyal és annak lakhelyével, a Pélion-hegység-gel, ,,amelyről nyugodtan állíthatjuk, hogy az ókori görög világ Pilise, minthogy méréseink szerint valóban együtt pulzál a Pilissel!” (Born é. n., erről 1. még IMREH 2014: 111).

4.4. A hangalak módosításának módjai. Ahhoz, hogy két, valamelyest eltérő hangokból álló szót össze lehessen kapcsolni, az egyes hangok módosítására van szükség. Gyakorta nem is hangokról, hanem a szó írásos formájáról, a betűkről van itt szó. A módosításra több szerző szerint az jogosítja fel az etimológust, hogy a szavak alakja módosult az idők folyamán, így csupán a változások visszafejtéséről van szó, ami szükséges a szó eredeti értelmének megtalálásához. A nyelv változása Szókratész elmondása szerint az idők folyamán végbement természetes folyamat, de tudatos emberi törekvésre is történhetett a szép hangzás elérése érdekében (pl. 414 c-d / Platón 2008: 70). Sevillai Izidor ellenkező előjelü dologról beszél: ő barbarizmusként, azaz a latin nyelv tisztaságát elrontó folyamatként értelmezi az idők folyamán a latinban végbement hangalaki változásokat (I. könyv 32. 3. / Isidore 2010: 55). Ez utóbbi narratíva jelenik meg a magyar nyelv kortárs ,alternatív” rokonítási kísérleteinek szómagyarázataiban is, a szándékos pusztítást is feltételezve, ahogy például Práczki István a rovásírásos kultúremlékek, dokumentumok, könyvtárak módszeres pusztításáról, az ősi magyar nevek latin és görög betüs átírásának rettenetes következményeiröl ír (1998: 8-9).

Mind Szókratész (394 b / Platón 2008: 35), mind Izidor (I. könyv 32. 3 / Isidore 2010: 55) a következő négy változást sorolja fel: betűk hozzáadása, elvétele, kicserélése és felcserélése. Ugyanez szerepel Varrónál is (additio, demptio, traiectio, commutatio), de ő még hozzáteszi ehhez a szótagok nyújtását és rövidítését, valamint hozzáadását és törlését is (5. könyv 6. / Varro 1938: 6-9). Illusztrálásképp, a Poszeidón név magyarázata során a Kratülosz-beli filozófus a betü/hang hozzáadását és kicserélését is felhasználja háromféle származtatásában. A Poszeidón név ezek szerint jöhet a 'lábat bilincselő' jelentésű Poszideszmosz szóból (mert a tenger feltartóztatja a benne haladót), amelyhez az e-t talán a szép hangzás miatt adták hozzá; a polla eidósz - azaz 'sokat tudó' kifejezésből is származhat, amelyben az idők folyamán a két $l$-t egy $s z$ váltotta fel; vagy a ho szeión '[földet] rengető' kifejezésből is, egy $p$ és egy $d$ hozzádásával (402 e-403 a / Platón 2008: 51).

A hangok változtatása a szófejtés során legtöbbször nem tudatos, hanem inkább intuitív tevékenység, a fenti módozatok pedig inkább elméletté formálásai annak a kreatív tevékenységnek, amely a modern tudomány előtti és kívüli szófejtésekre jellemző. A hangok módosításainak egyéb fajtái is megfigyelhetőek. Ilyen a szó ismételgetése révén a szóhatár átrendezése is, mint például ahogy az a Kratüloszban történik a Héra istennév összekapcsolásakor az aér 'levegő' jelentésü szóval (404 c / Platón 2008: 53). De visszafelé olvasással is értelmet lelhetnek egy-egy szóban: Práczki István kortárs szerző például a Diána név visszafelé olvasásával és a kapott szót némileg módosítva találta meg az 'anyád' jelentést (1998: 78). 
4.5. Magyarázat idegen szóból/szavakból. Az azonos nyelv szavaiból, szintagmáiból való származtatás mellett a más nyelvekből való eredeztetés is jellegzetes módszer a modern tudomány előtti és azon kívüli kortárs etimológiákban. A Kratüloszban Szókratész a más nyelvből magyarázást mintegy az értelemadás utolsó lehetőségeként mutatja be, és elvként is rögzíti. Ez a módszer szerinte abban az esetben alkalmazható, ha a névmagyarázónak már semmi más nem jut eszébe a saját nyelvén belül, viszont a vizsgált lexéma felidéz számára egy más nyelvi szóalakot - mint a 'tűz' jelentésű pür szó, amit a filozófus egy hasonló alakú és azonos jelentésü fríg szóval kapcsol össze (409 d-410 a / Platón 2008: 62-63; a fríg egyébként szintén indoeurópai nyelv). A szavak eredetének jellegzetes típusairól szóló, már említett rövidke fejezetében Sevillai Izidor is számon tartja az idegen származtatás lehetőségét, elkülönítve a görögből magyarázástól.

A nemzeti öntudatra ébredés, a vulgáris nyelvek felértékelődése után az anyanyelv eredetének kutatását a nemzetépítés szolgálatába is állították, ami a modern tudomány elötti és azon kívüli etimológiára is jelentős hatással volt és van manapság is. Az etimologizálás ugyanis a néperedet keresésének egyik eszközévé vált: a szókincs elemeinek más nyelvek szavaira való visszavezetése által az adott nép kapcsolatba hozható nagy múltú, régi írásbelisége-kultúrája, hódításai, fejlett civilizációja stb. miatt magas presztízsünek tartott népekkel. Ez figyelhető meg a magyar nyelv mindenkori rokonításaiban (1. HEGEDŰS 2003), beleértve a kortárs ,alternatív” nyelvrokonításokat is (1. pl. a sumermagyar, hun-magyar nyelvrokonság elméletét). Viszont a 16. századi holland Goropius korábban már ismertetett munkássága is mutatja, hogy ez a jelenség nem magyar sajátosság, hanem univerzális tendencia, amelyek megjelenése inkább a korszellemröl, az aktuális társadalom-lélektani helyzetről árulkodik.

4.6. Párhuzamosan érvényes magyarázatok. A modern etimológiával szemben a tudomány előtti és azon kívüli etimologizálás egyik tipikus vonása, hogy egy adott szóhoz több ,megfejtést” is felsorakoztat, melyek között az érvényesség szempontjából általában nem rangsorol (BLUM 2012: 33). Megfigyelhető ez a Kratüloszban (1. korábban Poszeidón példáját), a Védákban (BRONKHORST 2001: 6-7), Varrónál (DEL BELLO 2007: 89), Izidornál (BLUM 2012: 57-58) és Voraginénél is (1. korábban a Katalin példáját). Ez a kortárs ,alternatív” nyelvrokonítások etimológiáira is jellemző. Például a Pilis-kultuszban a Pilis helynévhez számos különféle magyarázat kapcsolódik, de egyik sem a kizárólagosság igényével jött létre, jól tolerálják egymást, ahogy azt az egyik Pilis-kutató következő megjegyzése is mutatja: „A »Pilis« szó jelentései közül a talán kevésbé ismert [a] sumér Pilsu, jelentése: »törés «" (Simon 2012: 17, bővebben l. IMREH 2014).

DAVIDE DEL BELLO ezekre - föleg a többjelentésüségük miatt - az allegorikus etimológia (allegorical etymology) kifejezést használja. Ennek fő jellemzői, hogy a név nem egy fogalomra, tárgyra, eseményre utal, hanem allegorikusan jelentések sokaságát hordozza, amelyek részenként, de egyformán igazak. Például az antik etimológus történeti, mitológiai körülményeket vagy filozófiai tartalmakat éleszt föl a szófejtéseiben, az etimologizált szóhoz több, helyesnek vélt magyarázatot is füz, amelyeket retorikailag és képletesen, tömörítéssel sürít egy-egy tulajdonnévbe vagy szóba. Az allegorikus név így narratívákat sürít, történetmesélést indíthat el. Ebben a felfogásban a név ,a jelentése allegóriája", és nincs egyetlen, egyedüliként helyes vagy ideális értelme. (DEL BELLO 2007: 57, 63-66.) 
JOHANNES BRONKHORST az allegorikus etimológiá-nak megfeleltethető szemantikai etimológia (semantic etymology) kifejezést alkalmazza Szókratész etimológiáira. Ez a típusú szómagyarázat szerinte univerzális jelenségként jelenik meg az antik müveltségben, mitológiában, az Európán kívüli és természeti népek kultúrájában, mítoszaiban. A mai, tudományos történeti etimológiákkal szemben - amelyek a szavak eredetéről, történetéről adnak felvilágosítást - , a szemantikai etimológia egy szót egy vagy több másikkal kapcsol össze, amelyekröl úgy tartják, hogy megvilágosítják az eredeti szó értelmét”. Így a szemantikai etimológiák ,nem a szó történetéröl beszélnek, hanem a jelentésükröl mondanak el valamit"1 (BRONKHORST 2001: 147-148, ford. I. R.).

5. A népi eredetmagyarázatok és a népetimológia nem tudatos következményei, hatásai a kultúrára, gondolkodásra. A vizsgált, tudomány előtti és tudományon kívüli szófejtések olykor nem maradnak meg a nyelvi tudat szintjén, hanem azon túllépve különféle formákban lecsapódhatnak a kultúra különböző területein. A továbbiakban ezt négy, különböző területről hozott példával szemléltetem. Egy-egy szó, tulajdonnév népi értelmezése kisebb cselekvésekben, szabályokban megnyilvánuló mindennapi hiedelmek és népszokások kialakulását mozdíthatja elő, például egyes élőlényekkel, azok viselkedésével vagy az egyes naptári napokkal kapcsolatban (1. 5.1). A nevek népi magyarázatai a vallási életre, vallási hiedelmekre, szokásokra is hatással vannak: például egyes szentek kultuszának - védőszenti státuszuknak, ábrázolásmódjuknak - létrejöttében is szerepet játszhatnak az általuk viselt személynévből fakadó asszociációk (1. 5.2). A tulajdonnevek értelmesítése nyomot hagyhat a vizualitásban is: erre látható példa a szentnevek kapcsán az ikonográfiában, a helynevek kapcsán pedig a heraldikában az ún. beszélő címerek (BÁRCZAY 1897: 26) esetében (1. 5.3). A népi, laikus névmagyarázatok a fogyasztói szokásokat is befolyásolhatják: az erre építő reklám révén a vásárlóban pozitívabb attitűd alakulhat ki egy-egy termék iránt, így az jobban eladhatóvá válik (1. 5.4).

Itt a népi eredetmagyarázatokon kívül a népetimológiás alakulatok hatásairól, következményeiről is szó esik, amelyek ugyan más természetűek (szó- és névkeletkezési jelenségről van szó), de asszociációs hátterük hasonlósága miatt szoros kapcsolatban vannak az előbbiekkel, egymással határosak (vö. OLSCHANSKY 1996: 198-199).

5.1. Mindennapi hiedelmek, népszokás. Olykor a népetimológia és a népi eredetmagyarázat kihatással van a szó vagy név által jelölt dologgal kapcsolatban az ember gondolkodására, hiedelmeire, és ezáltal a mindennapi élet kisebb-nagyobb cselekvéseire is. Ilyen például a fülbemászó (hasonló motivációjú elnevezéssel más nyelvekben is, 1. ném. Ohrwurm, ang. earworm stb.) esete: a név eredeti motivációjának elhomályosodása után az a hiedelem kapcsolódott az állathoz, hogy belemászik a fülbe, holott nevét villás farka miatt, metaforikusan egy szerszámról kapta, amellyel a fülbevaló behelyezése előtt

\footnotetext{
1 ,A semantic etymology is to be distinguished from a historical etymology. A historical etymology presents the origin or early history of a word; it tells us, for example, that a word in a modern language is derived from another word belonging to an earlier language, or to an earlier stage of the same language. [...] Semantic etymologies do something different. They connect one word with one or more others which are believed to elucidate its meaning. [...] Semantic etymologies tell us nothing about the history of a word, but something about its meaning."
} 
a fülcimpát átlyukasztották (vö. ném. nyelvjárási Ohrkneifer 'fülcsípő', WEISGERBER 1957: 62-63). Hasonló lehet a fülemüle esete, amelyet manapság a köznapi ember a madár híresen szép éneke miatt előbb kapcsol össze a fül szóval, mintsem a görög mitológia Philomela nevével. A fülemüle végső soron görög eredetü latin jövevényszó, jelentése valószínüleg 'éneket kedvelő' (KISS 1984: 280).

A parlagfühöz is népetimológia révén kapcsolódott az az újabb keletü nézet, hogy allergizáló hatása mellett és ellenére értékes gyógynövényröl van szó. A növény latin neve ugyanis Ambrosia artemisiifolia, ebből fakadóan pedig a parlagfüről az a népi értelmezés járja, hogy az antik görög istenek táplálékával, az ambróziával azonos. A növény valójában Észak-Amerikából érkezett a 18. században, és a 19. században terjedt el Európában. Latin elnevezése Linnétől származik, aki kettős nevezéktanában - több ezer növény elnevezése során - olykor híres emberek neveit is felhasználta; jelen esetben Milánói Szent Ambrus egyházatyáét (Ambrosius) (KISS et al. 2012, JUHÁSZ 2013).

Nevek értelmesítésére, népi értelmezésére vezethetőek vissza egyes, a naptári napokhoz kötődő népszokások is. Ilyenek például a szentek nevein alapuló szokások, hiedelmek, tilalmak az adott szent ünnepnapján. Német nyelvterületen például Szent Bonifác napját a babvetésre tartották megfelelőnek - a Bonifaz név a ném. Bohnen 'bab' jelentésü szóval mutat hangalaki egyezést (de vö. lat. bonifatius 'jó sorsú'; DMNES. Boniface a.). Szent Gál (Gallus) napján nem volt szabad szüretelni, mert úgy hitték, hogy az aznapi szőlőből készült bor olyan keserü lesz, mint az epe, azaz németül Galle (de vö. kelta Gallo 'gall; az ilyen nevü néphez tartozó' 1. MUnk. Gallusz a.). A Vince-naphoz pedig borral kapcsolatos népszokások kötődnek Európa-szerte a személynévnek a 'bor' jelentésű szóval való, az újlatin, szláv, germán nyelvekben is meglévő hangalaki hasonlósága miatt (1. pl. fr. vin, horv. vino 'bor', de vö. Vince a lat. 'győző' jelentésű vincens szóból DMNES. Vincent a.; minderről 1. WEISGERBER 1957: 70-71, KNOBLOCH 1996). Hasonló példa német nyelvterületen a keddi napot jelölö Dienstag esete. Az e naphoz kötödö, szolgáltatás, szolgálat megkezdésével vagy cselédfogadással kapcsolatos népszokások a népetimológiás alaki változás eredményeként létrejött Dienstag szónak a 'szolgálat' fogalmával kapcsolatos asszociációja miatt alakultak ki (vö. ném. Dienst 'szolgálat', Dienstbote 'cseléd'). A nap neve ugyanakkor egy - a latin Mars istennek megfeleltethetö germán istenség (Thingsus) nevéből ered, hasonlóan az újlatin nyelvekben meglevő 'Mars napja' jelentésü napnevekhez (pl. fr. mardi, ol. martedi; 1. WEISGERBER 1957: 65-66).

5.2. Szentkultusz - vallási hiedelmek. A szentnevek interpretációi a vallási gyakorlatban is befolyásoló erővel bírhattak. Egyrészt megtámogatták a kultuszt: Szent Domonkos legendáiban például a kutya fontos szerepet játszik, amit a szerzetesrend latin nevén alapuló szójáték is erősít: dominicanes 'domonkosok' $\sim$ domini canes 'az Úr kutyái' (MKatLex. kutya, Domonkos a.).

A nem tudományos névinterpretációk a szent személyére irányuló tisztelet különböző aspektusainak megteremtésében is részt vehettek. Így ezek a névmagyarázatok, asszociációk sok esetben befolyásolták, hogy mely személyek, csoportok, tevékenységek védőszentjeivé váltak az adott személyek, és így milyen esetben szokás a közbenjárásukat kérni. A személynév német nyelvi áthallása révén lett például Szent Bálint a szerelmeseken kívül az epilepsziások védőszentje is. A név német változata, a Valentin ugyanis a ném. fallend hin azaz 'eleső' szókapcsolattal, és általa az epilepszia régies elnevezésével - fallende Sucht - cseng össze. A név egyébként a lat. valens 'erős, egészséges' melléknév 
származéka a DMNES. szerint (Valentine a.). Szent Balázs germán nyelvterületen időjárással kapcsolatos, valamint a szélmalmosokat, fúvós zenészeket oltalmazó, illetve a hólyagbetegségeket gyógyító patrónus a név német nyelvi megfelelőjének (Blasius) a ném. blasen 'fúj' jelentésű igével és a ném. Blase 'hólyag' jelentésű főnévvel való hangalaki hasonlósága miatt. Ugyanakkor délszláv és orosz nyelvterületen a hajproblémák esetén is érdemes hozzá fohászkodni, mert ott a név - Volos/Vlasij - a 'haj' jelentésü fönevet - volos/vlasy - idézi fel (KNOBLOCH 1996: 1856). A Balázs (Blasius) a DMNES. szerint bizonytalan eredetű név, talán a lat. blaesus 'dadogó, hebegő' jelentésű szóból ered (Blaise a.). Páduai Szent Antalhoz az elveszett dolgok megkerülése érdekében szokás imádkozni, ami valószínüleg Padova régi nevének - Paves - és a francia épaves 'gazdátlan, elveszett dolog' jelentésü szónak az összecsengése miatt alakulhatott így. Szüz Mária Stella Maris, azaz 'Tengernek csillaga' megjelölése is népetimológiás alakulat: Szent Jeromos a héber név korábbi Mar Jam interpretációját szó szerint a 'tengercsepp' jelentésü stilla maris latin szókapcsolatra fordította, amely a későbbi másolások során a 'tenger csillaga' jelentésü stella maris-ra módosult (minderről 1. BARDENHEWER 1880, WEISGERBER 1957: 70-71, KNOBLOCH 1996).

5.3. Képi ábrázolás. A szent nevének (félre)értelmezése tárgyiasult formában is megjelenhet: kihathat az adott személy ábrázolásmódjára is. Szent Kristófot például gyakran, főleg ortodox ikonokon kutyafejüként ábrázolták, ami valószínüleg származására utaló nevének - Cananeus 'kánaánita' népetimológiával canineus-ként ('kutyaszerü'ként) való félreértelmezéséből fakad (Ross 1996: 50).

A településnevek népi etimologizálásai öltenek testet egyes beszélő címerekben is (RUOFF 1995: 361). Berlin és Bern késő középkori címerében is medve (ném. Bär) szerepel, holott egyik város nevének tudományos eredeztetése sem erősítette meg a toponima állatnévi eredetét. A Berlin a FNESz. szerint jövevénynév, amely valószínủleg valamely szláv nyelvből származik, és személynévből vagy egy 'mocsár, ingovány' jelentésű közszóból eredhet. A Bern pedig a FNESz. alapján Verona középfelnémet Berne névváltozatának tudatos átvétele, vagy a kelta *berna 'hasadék, szakadék' szóból származhat az LSG. szerint. Budakalász címerébe is népetimológia révén került be a három kalász - a toponima valójában a káliz 'izmaelita' jelentésű népnévből eredő népetimológiás alakulat (FNESz.).

Családi címerek keletkezését is befolyásolhatták hasonló folyamatok. Az Elefánti család beszélő címerében egy elefánt szerepel. A névadó falu - Elefánt - nevének létrejötte kapcsán több magyarázat is született: a család őse Kálmán királynak egy elefántot és egy szerecsent ajándékozott, amiért a király falut adományozott neki, máshol az ôs egy elefántot kapott ajándékba Zsigmond királytól a neki tett hősi katonai szolgálataiért, vagy pedig háborúban elfogott egy elefántot, és azt a királynak adományozta (NAGY 1857-1868. 4: 24-25, HAJDÚ 2003: 67). Az Elefánt helységnév eredetéről két tudományos vélemény is ismeretes. KOROMPAY KLÁRA (1972) szerint a toponima a Roland kürtjének nevéből származó Olivant személynévből alakult népetimológiával. TÓTH ENDRE (2006) szerint viszont a falu legkorábbi (1113) említésekor az állat még nem lehetett olyan mértékben ismert Magyarországon, hogy neve népetimológiás folyamat végeredménye legyen, ezért ő inkább az Árpád-korból adatolható, ónémet eredetű Elephant személynévből származtatja, amely a Helfant ('segítő') ónémet személynév változata. Szerinte a név a magyarban később, az állat közismertté válásakor kapcsolódott össze népetimológiásan 
az állatnévvel. Bárhonnan is származik a toponima, a címerkép végső soron a népetimológiának köszönheti a létrejöttét.

5.4. Marketing, reklám. A tudomány előtti és tudományon kívüli etimológia utóélete a marketingben, reklámban is megfigyelhető. Egy-egy termék eladásakor olykor találó lehet a kapcsolódó név, szó közkeletű népi vagy laikus etimológiájához fordulni, mint ahogy a visegrádi Hotel Silvanus teszi, amikor a föleg a Dobogó-kö helynéven alapuló szívcsakratézisre hivatkozva invitálja az érdeklődőt testi-spirituális feltöltődésre. „Öseink nem véletlenül adták a terület középpontjában lévő csúcsnak a Dobogókő nevet” írja a weboldal a szívcsakrával kapcsolatos nézetek bemutatása után. ${ }^{2}$

6. Összegzés. A szavak, nevek etimologizálása, az eredetük, jelentésük iránti érdeklődés a különböző történelmi korszakokban meglévő univerzális jelenség. Ez manapság is jócskán túlnyúlik a modern tudomány szempontjából szakszerűnek tartott etimológiai kutatás keretein a laikusok, a mindennapi ember világába. A modern tudomány előtti, a népi és a kortárs laikus etimológiák mindenkori emberi szükségletet töltenek be. A modern tudományos etimológiával szemben - amelynek célja a tudományos megismerés ezek sokféle funkcióval bírnak: eszközként közremüködnek a világ megértésében, az abban való tájékozódásban, különböző jellegü célok szolgálatában.

Az ide sorolható szó- és névfejtések rendkívül sokfélék, és nagy terjedelmü vizsgálati anyagot adnak, amelyben ugyanakkor - mint látható volt - számos hasonlóság, tendencia felfedezhető. Noha a témakör számos terminológiai, kutatásmódszertani kérdést is felvet, e tanulmány a vizsgálat lehetségességére, lehetőségeire, irányaira kívánt rámutatni. A téma kutatásra érdemes a nevek funkcióinak, a mindennapi életben játszott szerepüknek, a névkultúrának, a nevekhez kapcsolódó hiedelmeknek és vélekedéseknek a szempontjából is. Így a napjainkban szárnyat bontó folkonomasztika (népi névtan, folk onomastics, 1. AINIALA 2016: 378-380, GYÖRFFY 2018: 20), illetve a manapság egyre inkább kibontakozó alkalmazott névtan számára is gyümölcsöző lehet a vizsgálatuk.

\section{Felhasznált források}

Arisztotelész 1982. Rétorika. Gondolat Kiadó, Budapest.

Augustine 1975. De dialectica. Ed. Pinborg, Jan. Synthese Historical Library - Texts and Studies in the History of Logic and Philosophy 16. D. Reidel Publishing Company, Dordrecht-Boston.

Babits Mihály 1938. Káp isten. Nyelvtudományi humoreszk. In: Babits Mihály, Babits Mihály összes novellái. Babits Mihály összegyüjtött munkái 8. Athenaeum, Budapest. 371-374.

Biblia 2006. = Biblia. Ószövetségi és Újszövetségi Szentírás. Szerk. Rózsa Huba. Szent István Társulat, Budapest, 2006.

Bobula Ida 1970. Kétezer magyar név sumir eredete. Gönczöl Kiadás, Montreal.

Born Gergely é. n. A Pilis csodálatos titka. http://gagbi-babca.blogspot.com/2008/01/pilis-csodlatostitkai-1.html

Czakó Gábor 2008. Beavatás a magyar észjárásba. Cz. Simon Bt., Budapest.

\footnotetext{
${ }^{2}$ https:/hotelsilvanus.hu/hu/hotel/wellness-spa/bioenergetikai-kozpont (2019. 10. 10.)
} 
Czakó Gábor 2011. Eredeti magyar nyelvtan: a magyar nyelv természeti rendje szerint, Czuczor Gergely és Fogarasi János nyomán. Cz. Simon Bt., Budapest.

Érszegi Géza szerk. 1987. Árpád-kori legendák és intelmek. Szépirodalmi Könyvkiadó, Budapest. Faragó Imre 2016. Ber, Bere, Berény avagy helynévadás a Kárpát-térségben. Fríg Kiadó, Budapest.

Hésziodosz 1974. Istenek születése. Munkák és napok. Európa Könyvkiadó, Budapest.

Horvát István 1825. Rajzolatok a' magyar nemzet legrégibb történeteiböl. Trattner, Pest.

Isidore of Seville 2010. The Etymologies of Isidore of Seville. Cambridge University Press, Cambridge.

Kliment Emilia 2005. Névmágia. Hogyan befolyásolja a név személyiségünket. LPI Produkciós Iroda Kft., [Budaörs].

Petőcz Mihály 1840. Régi magyar szavak. Pozsony.

Platón 2008. Platón összes müvei kommentárokkal. Kratülosz. Atlantisz, Budapest.

Simon Tamás 2012. A Pilisben müködő erők III. rész: Sárkány a Pilisben. Dobogókő - a Királyi Központ Lapja 22: 12-19.

Sipos Ferenc 2012. Nevében él a nemzett. Magyar keresztnevek részletes eredettörténete. Noran Libro Kiadó, Budapest.

Takács Tibor é. n. „Nomen est omen” (A névelemzö tanfolyam anyaga. Csak belsö használatra.). K. n., H. n.

Varga Csaba 2003. A kökor élö nyelve. Fríg Kiadó, Pilisszentiván.

Varro 1938. On the Latin Language 1-2. William Heinemann Ltd. -Harvard University Press, London-Cambridge (MA). http://www.attalus.org/info/varro.html

Voragine, Jacobus de 1990. Legenda Aurea. Szerk. Madas Edit. Helikon, Budapest.

\section{Hivatkozott irodalom}

Ainiala, Terhi 2016. Names in Society. In: Hough, Carole ed., The Oxford Handbook of Names and Naming. Oxford University Press, Oxford. 371-381. https://doi.org/10.1093/oxfordhb/ 9780199656431.013.27

BALÁzs GÉZA 2008. A helynevek antropológiai nyelvészeti szempontból. Magyar Nyelvőr 132: 348-354.

BÁRCZAY OSZKÁR 1897. A heraldika kézikönyve: müszótárral, 714 szövegközti ábrával és 3 melléklettel. Magyar Tudományos Akadémia, Budapest.

BARDENHEWER, OTTO 1880. Woher stammt Stella Maris? Zeitschrift für katholische Theologie 4: 387-389.

BENKÖ LORÁND 1998. Helynév-személynév-történés korrelációjának szerepe P. magiszter munkamódszerében. In: BENKÖ LORÁND, Név és történelem. Tanulmányok az Árpád-korról. Akadémiai Kiadó, Budapest. 11-27.

BLUM, ANDREAS 2012. Etymologische Erklärungen in alfonsinischen Texten. Beihefte zur Zeitschrift für romanische Philologie 340. Walter De Gruyter, New York - Berlin. https://doi.org/ $\underline{10.1515 / 9783110939750}$

BöRÖCZKI TAMÁs 2008. Utószó. A nevek és a dolgok. In: Platón, Platón összes müvei kommentárokkal. Kratülosz. Atlantisz, Budapest. 117-142.

BronKhorst, Johannes 2001. Etymology And Magic. Yåska's Nirukta, Plato’s Cratylus, and the riddle of semantic etymologies. Numen 48: 147-203. https://doi.org/10.1163/156852701750152645

CURTIUS, ERnst Robert 1953. Etymology as a Cathegory of Thought. In: CURTIUs, ERnST RoBERT, European Literature and the Latin Middle Ages. Pantheon Books, New York. 495-500. 
CzF. = CZuCzor Gergely - Fogarasi JÁnOs, A magyar nyelv szótára 1-6. Emich Gusztáv / Athenaeum, Pest/Budapest, 1862-1874.

David, Jaroslav 2009. Folk Etymology in the Middle Ages Czech Chronicles (from Cosmas to Hájek). Beiträge zur Namenforschung 44: 419-430.

Del Bello, Davide 2007. Forgotten Paths. Etymology and the Allegorical Mindset. The Catholic University of America Press, Washington D. C. https://doi.org/10.2307/j.ctt284vxj

DÉva 2010. Marihónalja és mojirtó. Modern népetimológiák. Nyelv és Tudomány 2010. május 5. https://www.nyest.hu/hirek/marihonalja-es-mojirto

DMNES. = The Dictionary of Medieval Names from European Sources. Editor-in-chief: UCKELMAN, SARA L. Edition 2018/1. http://dmnes.org/

DomaradZKi, Mikolaj 2012. Theological Etymologizing in the Early Stoa. Kernos 25: 125-148. https://doi.org/10.4000/kernos.2109

DÖMÖTÖR ADRIENNE 1991. Népi helynév-etimológiák. Magyar Nyelvör 115: 125-127.

ECO, UMBerto 1995. The search for the perfect language. Blackwell, Oxford-Cambridge.

EDG. = BEEKES, ROBERT - VAN BEEK, LUCIEN, Etymological Dictionary of Greek 1-2. Leiden IndoEuropean Etymological Dictionary Series 10/1-2. Brill, Leiden-Boston, 2010.

EDLOIL. = DE VAAN, Michiel, Etymological Dictionary of Latin and Other Italic Languages. Leiden Indo-European Etymological Dictionary Series 7. Brill, Leiden-Boston, 2008.

FARKAS TAMÁS 2006. Keresztnévkönyvek - keresztnévtárak - keresztnévszótárak Magyarországon. In: Mártonfi AtTila - PAPP KornÉlia - Slíz Mariann szerk., 101 írás Pusztai Ferenc tiszteletére. Argumentum, Budapest. 246-252.

FARKAS TAMÁS 2019. Történelemkonstruálás - névkonstruálás. A honfoglalás, illetve a korai magyar történelem személynevei és az utókor. Névtani Értesitö 41: 75-90. https://doi.org/10.29178/ NevtErt.2019.4

FNESz. = KISS LAJOS, Földrajzi nevek etimológiai szótára 1-2. 4., bővített és javított kiadás. Akadémiai Kiadó, Budapest, 1988.

GYÖRFFY ERZSÉBET 2011. A szleng helynevek névrendszertani helyéröl. Névtani Értesítő 33: 93-99.

GYÖRFFY ERZSÉBET 2018. Helynév-szociológia. A Magyar Névarchívum Kiadványai 47. Debreceni Egyetemi Kiadó, Debrecen.

HAJdÚ MihÁly 2003. Általános és magyar névtan. Személynevek. Osiris, Budapest.

HALÁsz IGNÁCZ 1900. A magyar szófejtés története a legrégibb időktől Hunfalvi Pál fölléptéig. Akadémiai Értesitö 129: 5-19.

HaLÁSz IGNÁCZ 1903. A magyar szófejtés és történeti fejlődése. Nyelvtudományi Közlemények 33: $1-45$.

HEGEDŰS JÓzSEF 2003. Hiedelem és valóság. Külföldi és hazai nézetek a magyar nyelv rokonságáról. Akadémiai Kiadó, Budapest.

Hendel, Ronald S. 2000. Adam. In: Freedman, David Noel ed., Eerdmans Dictionary of the Bible. Eerdmans, Grand Rapids - Cambridge. 18-19.

HeRBERMANN, Clemens-Peter 1981. Moderne und antike Etymologie. Zeitschrift für vergleichende Sprachforschung 95: 22-45.

HOHENSINNER, KARL 2015. Flurnamen in Oberösterreich - Historische Quellen, Erfahrungen und neue Forschungsperspektiven. In: AEHNLICH, BARBARA - MeInEKe, ECKHARD Hrsg., Namen und Kulturlandschaften. Onomastica Lipsiensia - Leipziger Untersuchungen zur Namenforschung 10. Leipziger Universitätsverlag GMBH, Leipzig. 105-157.

IMREH RÉKA 2014. A helynevek szerepe az alternatív ideologikus gondolkodásban I. A Piliskultusz esete. Névtani Értesitö 36: 105-120. 
IMREH RÉKA 2015. A helynevek szerepe az alternatív ideologikus gondolkodásban II. Tudálékos helynév-etimológiák és új helynevek a Pilis-kultuszból. Névtani Értesitö 37: 119-136.

JuHÁsz MiKLós 2013. Az istenek eledele? AMEGA Allergológia 2013. aug. 29-32. http://pme.hu/ wp-content/uploads/2014/05/istenek eledele.pdf

KÁlmÁn Béla 1976. A népetimológia. In: BENKÖ LORÁND - K. SAl Éva szerk., Az etimológia elmélete és módszere. Nyelvtudományi Értekezések 89. Akadémiai Kiadó, Budapest. $165-169$.

Kanavou, Nikoletta 2015. The Names of Homeric Heroes. Walter De Gruyter, New York Berlin.

KISS JENŐ 1984. Magyar madárnevek. Az európai madarak elnevezései. Akadémiai Kiadó, Budapest.

KISS TIVADAR - CSUPOR DEZSÖ - SZENDREI KÁLMÁN 2012. Gyógynövény-e a parlagfü? Gyógyszerészet 56/1-2: 1-7. http://publicatio.bibl.u-szeged.hu/3094/1/2063727\%20Kiss Gyogyszereszet2012-09.pdf

KLINCK, Roswitha 1970. Die lateinische Etymologie des Mittelalters. Medium Aevum - Philologische Studien 17. Fink, München.

KnE. = FERCSIK ERZSÉBET - RAÁTZ JUdit, Keresztnevek enciklopédiája. A leggyakoribb nöi és férfinevek. A Magyar Nyelv Kézikönyvei 16. Tinta Könyvkiadó, Budapest, 2009.

KNOBLOCH, JOHANN 1996. Namen christlicher Heiligen. In: EICHLER, ERNST et al. eds. 1995-1996. Namenforschung / Name Studies / Les noms propres. Ein internationales Handbuch zur Onomastik / An International Handbook of Onomastics / Manuel international d'onomastique. HSK. 11.1-2. Walter de Gruyter, Berlin - New York. 1856-1859. https://doi.org/10.1515/ 9783110148794.2.23.1856

KOROMPAY KLÁRA 1972. Elefánt. Magyar Nyelv 68: 174-179.

KovAlOVSZKY MikLós 1967. Újabb népetimológiáinkról. In: IMRE SAMU - SZATHMÁRI IsTVÁN szerk., A magyar nyelv története és rendszere. A debreceni nemzetközi nyelvészkongresszus elöadásai. Nyelvtudományi Értekezések 58. Akadémiai Kiadó, Budapest. 244-249.

Krop, HenRi A. 2016. The antiquity of the Dutch language. Renaissance theories on the language of Paradise. In: FenOulhet, JANE - Gilbert, LeSLEY eds., Narratives of Low Countries History and Culture. Reframing the Past. UCL Press, London. 108-124. https://doi.org/10.2307/ j.ctt1hd18bd.15

KUGLER NÓRA 1993. Népetimológia és/vagy az értelmiség elmeéle a ragadványnévadásban. Névtani Értesitö 15: 205-206.

LSG. = KRISTOL, ANDREAS, Lexikon der schweizerischen Gemeindenamen (LSG) / Dictionnaire toponymique des communes suisses (DTS) / Dizionario toponomastico dei comuni svizzeri (DTS). Université de Neuchâtel, Centre de dialectologie et d'étude du français régional. HuberPayot, Frauenfeld-Lausanne, 2005.

MadAs EdiT 1990. Utószó. In: Jacobus de Voragine, Legenda Aurea. Helikon, Budapest. 315-322.

Males, Mikael ed. 2018. Etymology and Wordplay in Medieval Literature. Brepols, Turnhout. https://doi.org/10.1484/M.DISPUT-EB.5.113328

MaLKIel, Yakov 1993. Etymology. Cambridge University Press, Cambridge.

MKatLex. = Magyar katolikus lexikon 1-15. Főszerk. Diós IstVÁN. Szent István Társulat, Budapest, 1993-2010.

MóRICZ KÁLMÁN 2013. Kárpátaljai népi helységnév-magyarázatok, mondák. In: BALÁzs GÉZA GRÉTSY LÁsZLÓ szerk., Helyneveink érdekességei, tanulságai, népi magyarázatai. Egy pályázat legjobb darabjai. Anyanyelvápolók Szövetsége - Tinta Könyvkiadó, Budapest. 216-224. 
MUnk. = LADÓ JÁNOS - BíRÓ ÁGNES, Magyar utónévkönyv. Bővített kiadás. Vince Kiadó, Budapest, 2016.

NAGY IVÁN 1857-1868. Magyarország családai czimerekkel és nemzedékrendi táblákkal 1-12. Beimel J. - Kozma Vazul, Pest.

NÉMETH ReNÁTA 2007. A XIX. századi nyelvbölcselet és A magyar nyelv szótárának etimológiai elvei. Doktori $(\mathrm{PhD})$ értekezés. Eötvös Loránd Tudományegyetem Bölcsészettudományi Kar, Budapest. http://doktori.btk.elte.hu/lingv/nemethrenata/disszert.pdf

NéprLex. = Magyar néprajzi lexikon 1-5. Főszerk. ORTUTAY GyULA. Akadémiai Kiadó, Budapest, 1977-1982.

OlsChANSKy, Heike 1996. Volksetymologie. Reihe Germanistische Linguistik 175. Niemeyer, Tübingen.

ROBINS, ROBERT HENRY 1999. A nyelvészet rövid története. Osiris - Tinta Kiadó, Budapest.

RÓNAI BÉLA 1982. A népetimológia földrajzi neveinkben. Névtani Értesítő 7: 9-18.

Ross, Leslie 1996. Medieval Art. A Topical Dictionary. Greenwood Press, Westport.

Rudnyckyj, Jaroslav B. 1966. Typology of Namelore. In: Blok, Dirk Peter ed., Proceedings of the 8th International Congress of Onomastics Sciences. Mouton, The Hague. 433-441. https://doi.org/10.1515/9783111349046-065

RuOFF, ARNO 1995. Naive Zugänge zur Namenforschung. In: EICHLER, ERNST et al. eds. 1995-1996. Namenforschung / Name Studies / Les noms propres. Ein internationales Handbuch zur Onomastik / An International Handbook of Onomastics / Manuel international d'onomastique. HSK. 11.1-2. Walter de Gruyter, Berlin - New York. 360-367. https://doi.org/10.1515/9783110114263. $\underline{1.2 .360}$

SÁNDOR KLÁRA 2011. Nyelvrokonság és hunhagyomány. Rénszarvas vagy csodaszarvas? Nyelvtörténet és müvelödéstörténet. Typotex, Budapest.

SLíz MARIANN 2011. Személynévadás az Anjou-korban. Históriaantik, Budapest.

SLíz MARIANn 2013. A tulajdonnév funkciója a görög mitológiában. Névtani Értesitő 35: 221-229.

SLíz MARIANN megj. e. A laikus keresztnévszótárak. In: FARKAS TAMÁS - SLíz MARIANN szerk., Tulajdonnevek és szótárak. Megjelenés elött.

SzIKSZAiNÉ Nagy Irma 2015. Onomasztikai játékok a költészetben. Acta Academiae Paedagogicae Agriensis. Sectio Linguistica Hungarica 42: 191-202.

TESz. = A magyar nyelv történeti-etimológiai szótára 1-3. Főszerk. BENKö LORÁND. Akadémiai Kiadó, Budapest, 1967-1976.

Tóтн ENDRE 2006. Az Elefánt helynév eredetéröl. Magyar Nyelv 102: 465-470.

Tо́тH VALÉRIA 2008. Településnevek változástipológiája. A Magyar Névarchívum Kiadványai 14. Debreceni Egyetem Magyar Nyelvtudományi Tanszéke, Debrecen.

TRIER, JOST 2017. Etymologie. In: RITTER, JOACHIM - GRÜNDER, KARLFRIED - GABRIEL, GOTTFRIED Hrsg., Historisches Wörterbuch der Philosophie online. Schwabe, Basel. https://doi.org/10.24894/ HWPh.983

VenNEMANN, THEO 1999. Volksetymologie und Ortsnamenforschung. Begriffsbestimmung und Anwendung auf ausgewählte, überwiegend bayerische Toponyme. Beiträge zur Namenforschung 34: 269-322.

WeISGERBER, Leo 1957. Sprachliche Wirkungen in Sitte und Volksbrauch. In: WeISGERBER, Leo, Die Muttersprache im Aufbau unserer Kultur. Pädagogischer Verlag Schwann, Düsseldorf. 59-94.

WiegAND KÁROLY - CZANYUGA JózSEF szerk. 1864. 1168 Latin közmondás gyüjteménye. Iskolai és házi használatra. Lampel Róbert, Pest. 
ZELLIGER ERZSÉBET 2017. Földrajzi neveink eredetéről - másképpen. Gondolatok néhány közelmúltban megjelent kötet kapcsán. Névtani Értesitő 39: 183-190.

IMREH RÉKA

ORCID: https://orcid.org/0000-0002-5157-793X

ELTE Eötvös Loránd Tudományegyetem

Bölcsészettudományi Kar

\section{RÉKA IMREH, Applied onomastic aspects of name interpretation before or outside modern science}

The paper reviews the word and name interpretations that existed before and after the emergence of historical-comparative linguistics and that could be found outside and in parallel with it, including classical and medieval etymologization, folk, and contemporary lay etymologies. The research aims to find generalizable features in the sources selected for the purpose of this study in the neglected research field. The first part of the paper explores the reasons for the development of such etymologies at any given time in history, and seeks to define their non-scientific functions in the past and present day. The second part examines the typical methods and directions of these word and name interpretations. The third part focuses on the impacts that etymologies of this category can have on everyday life, human thinking and certain areas of culture. The aim of the study is to draw attention to the potential, possibilities and usefulness of studying etymologies created before or outside modern science as a direction of applied onomastics and folk onomastics. 